\title{
TERT NM_198253.2:C.1-146C>T
}

National Cancer Institute

\section{Source}

National Cancer Institute. TERT NM 198253.2:C.1-146C>T. NCI Thesaurus. Code

C131106.

A nucleotide substitution in the 5' promoter region of the TERT gene at a position that is 146 nucleotides upstream of the translation start site where cytosine has been mutated to thymine. 